\title{
Pelargonium quercetorum Agnew induces apoptosis without PARP or cytokeratin 18 cleavage in non-small cell lung cancer cell lines
}

\author{
NAZLIHAN AZTOPAL ${ }^{1}$, BUSE CEVATEMRE ${ }^{1}$, MEHMET SARIMAHMUT ${ }^{1}$, FERDAARI $^{1}$, \\ EGEMEN DERE $^{1}$, MUSTAFA ZAFER OZEL ${ }^{2}$, MEHMET FIRAT $^{3}$ and ENGIN ULUKAYA ${ }^{4}$ \\ ${ }^{1}$ Department of Biology, Faculty of Science and Arts, Uludag University, Bursa 16059, Turkey; \\ ${ }^{2}$ Department of Chemistry, University of York, York YO10 5DD, UK; ${ }^{3}$ Department of Biology, Yuzuncu Yil University, \\ Van 65080; ${ }^{4}$ Department of Medical Biochemistry, Faculty of Medicine, Uludag University, Bursa 16059, Turkey
}

Received June 19, 2015; Accepted June 2, 2016

DOI: $10.3892 / \mathrm{ol} .2016 .4779$

\begin{abstract}
Pelargonium species have various uses in folk medicine as traditional remedies, and several of them have been screened for their biological activity, including anticancer. Pelargonium quercetorum Agnew (P. quercetorum) is traditionally used for its anthelminthic activity. However, little is known about its biological activity or its effect on cancer cells. The aim of the present study was to determine the cytotoxic activity of $P$.quercetorum extract on lung cancer cell lines with varying properties. Following the analyses of its chemical composition, the cytotoxic activity was screened by the adenosine triphosphate viability test. M30-Apoptosense $^{\circledR}$ and M65 EpiDeath ${ }^{\circledR}$ enzyme-linked immunosorbent assays were used to determine the cell death mode (apoptosis vs. necrosis). For apoptosis, additional methods, including Annexin-V-fluorescein isothiocyanate (FITC) and Hoechst 33342 staining, were employed. The cleavage of poly (adenosine diphosphate-ribose) polymerase (PARP) was assayed by western blotting to further dissect the apoptosis mechanism. The methanol extract of P. quercetorum caused cytotoxic activity in a dose-dependent manner. The mode of cell death was apoptosis, as evidenced by the positive staining of the cells for Annexin-V-FITC and the presence of pyknotic nuclei. Notably, neither PARP cleavage nor cytokeratin 18 fragmentation were observed. P.quercetorum caused cell death by an apoptosis mechanism that is slightly different from classical apoptosis. Therefore, future in vivo experiments are required for further understanding of the effect of this plant on cancer cells.
\end{abstract}

Correspondence to: Professor Engin Ulukaya, Department of Medical Biochemistry, Faculty of Medicine, Uludag University, Görükle Campus, Bursa 16059, Turkey

E-mail: eulukaya@uludag.edu.tr

Key words: Pelargonium quercetorum Agnew, lung cancer, herbal medicine, cytotoxicity, apoptosis

\section{Introduction}

Lung cancer is an aggressive and heterogeneous malignancy, and one of the leading causes of cancer-associated mortalities in men throughout the world (1). Although lung cancers are treated by surgical, radiotherapeutic and chemotherapeutic approaches, the long-term survival rate is still not satisfactory $(1,2)$. Therefore, novel approaches/compounds are still required to increase the success of treatment.

The use of medicinal plants for the treatment of human diseases begins with the history of humanity, and represents the oldest and most widespread form of medication due to their healing properties $(3,4)$. Several types of plants are important as a source of effective anticancer agents, which indicates their therapeutic values (5). Pelargonium species are widely used as traditional remedies for several diseases in Southern Africa (6). A number of herbs belonging to the genus Pelargonium possess numerous properties that have medicinal importance. For example, 'Umckaloabo', ethanol extracts of the root of two species of Pelargonium ( $P$. sidoides and P. reniforme), have been used in gastrointestinal, hepatic and respiratory diseases as a herbal remedy (7). Pelargonium species are rich in essential oils that are the source of their therapeutic value $(8,9)$. Among these, Geranium monoterpene oils exhibit anti-bacterial, antifungal antioxidant, insecticidal, anthelmintic and anticancer activity (7-13). There are also several Pelargonium species used in folk medicine that have been screened for their biological activities (Table I) $(8,12,13,14-26)$.

Pelargonium quercetorum Agnew (P.quercetorum) belongs to Geraniaceae family, and is known as Tolk in Gecitli, in the Hakkari province of Turkey (27). Kaval et al (27) reported that native people have used this plant to treat intestinal worms, and that study was the first report about the traditional use of $P$. quercetorum. However, to the best of our knowledge, there is no information regarding the cytotoxic activity of $P$.quercetorum against lung cancer cell lines in the literature.

In the present study, the anti-growth/cytotoxic effects of the methanol extract of $P$.quercetorum against non-small cell lung cancer cell lines (A549, PC3 and H1299) were investigated. The results demonstrated that $P$. quercetorum had cytotoxic activity in a dose-dependent manner, and resulted in an incomplete apoptosis, implying the requirement of 
further in vivo experiments for the elucidation of its cell death mechanism.

\section{Materials and methods}

Plantmaterial. The whole plant of P.quercetorum was collected from the Zap Valley at Sumbul Mountain in the Hakkari province of Turkey, located in the $\mathrm{C} 10$ square according to the Turkey's grid square system (28) in May 2006 by Mr. Mehmet Firat (Department of Biology, Yuzuncu Yil University, Van, Turkey). The specimen was identified using the standard text 'Flora of Turkey and the East Aegean lslands' (29). A voucher specimen (number MF.10111) was deposited in the Hacettepe University Herbarium (Ankara, Turkey).

Extraction of $P$. quercetorum sample. The sample was air-dried at room temperature, cleaned of extraneous materials and then grounded into powder. A total of $15 \mathrm{~g}$ of the material (trunk and flower parts) was extracted by adding $150 \mathrm{ml}$ of solvent methanol (Merck Millipore, Darmstadt, Germany) in a Soxhlet apparatus for $24 \mathrm{~h}$, and the crude extract was concentrated in a rotary evaporator at $40^{\circ} \mathrm{C}$. The residues were lyophilized and stored at $-80^{\circ} \mathrm{C}$ until used.

Determination of $P$. quercetorum chemical compounds Direct thermal desorption (DTD). To evaluate the volatile compounds present in $P$. quercetorum, DTD followed by analysis with comprehensive two-dimensional gas chromatography-time-of-flight/mass spectrometry (GCxGC-TOF/MS) was performed. The plant was directly loaded into the system. A GCxGC-TOF/MS system was used together with a dual stage commercial thermal desorption injector, which incorporated a thermal desorption unit (TDU) connected to a programmable-temperature vaporization injector [Cooled Injection System (CIS)-4 Plus; Gerstel, Mülheim an der Ruhr, Germany], using a heated transfer line. The injector was equipped with a MultiPurpose Sample (Gerstel). Empty glass thermodesorption tubes were conditioned at $400^{\circ} \mathrm{C}$ for $2 \mathrm{~h}$ prior to each use. Approximately 20-30 mg sample was placed into the thermodesorption tubes using tweezers to ensure no contamination of the sample. The initial desorption of the sample was conducted by heating the TDU from $40^{\circ} \mathrm{C}$ (initial time, $0.2 \mathrm{~min}$ ) to $150^{\circ} \mathrm{C}$ at a rate of $120^{\circ} \mathrm{C} / \mathrm{min}$ with a final hold time of 10 min under a helium flow of $1.5 \mathrm{ml} / \mathrm{min}$ in splitless mode. Volatile analytes released from this heating were cryo-focused at $-40^{\circ} \mathrm{C}$ in the CIS, which was cooled with liquid nitrogen prior to injection. The CIS was then heated at a rate of $10^{\circ} \mathrm{C} / \mathrm{sec}$ to a final temperature of $150^{\circ} \mathrm{C}$. Analytes were transferred splitless to the GC column during the CIS temperature ramp.

Chromatographic analysis. The GCxGC-TOF/MS system consisted of a 6890 GC (Agilent Technologies, Inc., Santa Clara, CA, USA) and a Pegasus III TOF-MS system (LECO Corporation, Saint Joseph, MI, USA). The modulator between the first and second GC columns was based on a LECO liquid nitrogen two-stage cold jet system. Helium was used as a carrier gas at a constant flow of $1.0 \mathrm{ml} / \mathrm{min}$. The first column was a non-polar BPX5 (30 mx0.32 mm i.d. x0.25 $\mu \mathrm{m}$ film thickness), while the second column was a BPX50
(1.5 mx0.10 mm i.d. x0.10 $\mu \mathrm{m}$ film thickness), both from SGE Analytical Science (Victoria, Australia). The combination of separations produced the overall two-dimensional chromatogram. Peak identification was performed using TOF/MS with electron ionization.

\section{Determination of cytotoxic activity}

Cell culture and chemicals. Non-small cell lung cancer cell lines A549, H1299 (Dr Donner, Walther Oncology Center, Indiana University School of Medicine, Indianapolis, IN, USA) and PC3 (Dr Yokota, National Cancer Center Research Institute, Division of Genome Biology, Tokyo, Japan) were cultured in RPMI-1640 (Lonza Bioscience, Verviers, Belgium) medium supplemented with L-glutamine (Gibco ${ }^{\circledR}$; Thermo Fisher Scientific, Inc., Waltham, MA, USA), $10 \%$ fetal bovine serum (Lonza Bioscience), penicillin $\mathrm{G}(100 \mathrm{U} / \mathrm{ml})$ and streptomycin $(100 \mu \mathrm{g} / \mathrm{ml})$ (HyClone; GE Healthcare Life Sciences, Logan, UT, USA) at $37^{\circ} \mathrm{C}$ in a humidified atmosphere containing $5 \% \mathrm{CO}_{2}$. According to the American Type Culture Collection (Manassas, VA, USA), PC3 is often known as a prostate cancer cell line (CRL1435), but in the present study, it represents a non-small cell lung cancer cell line derived from the Japanese Collection Research Resources Bank (Osaka, Japan; JCRB, JCRB0077).

The lyophilized $P$. quercetorum extract (PQE) was dissolved in dimethyl sulfoxide (DMSO; Sigma-Aldrich, St. Louis, MO, USA) at a concentration of $100 \mathrm{mg} / \mathrm{ml}$ as a stock solution, aliquoted and stored at $-80^{\circ} \mathrm{C}$. PQE was used at different concentrations ranging from 3.13 to $100 \mu \mathrm{g} / \mathrm{ml}$, and the dilutions were made in culture medium.

Adenosine triphosphate (ATP) assay. The ATP assay, a highly sensitive luciferin:luciferase-based assay, was performed to determine the level of cellular ATP as an indirect marker of the number of alive cells present in the sample (30). A549, PC3 and H1299 cells were seeded at a density of $1 \times 104$ cells/well in a 96 -well plate in $200 \mu 1$ medium. Cells were incubated either alone (as control) or in the presence of PQE for $48 \mathrm{~h}$. The untreated/control cells received vehicle only (0.1\% DMSO) without any drugs (which represented the maximum viability). Each experiment was conducted at least twice in triplicates. At the end of the treatment period (48 h), cell viability was determined by ATP assay with an ATP bioluminescent somatic cell assay kit (Sigma-Aldrich), according to the manufacturer's protocol with a slight modification, as explained previously (31). Morphological changes of cells were also observed under a phase-contrast microscope (CKX41; Olympus Corporation Tokyo, Japan).

\section{Determination of cell death mode}

Annexin-V-fluorescein isothiocyanate (FITC) fluorescence imaging for apoptosis. The translocation of phosphatidylserine (PS) molecules from the inner to the outer side of the cell membrane is one of the earlier events of apoptosis (32). Annexin-V-FITC is able to bind to PS, thus allowing the apoptotic cells to become visible. Propidium iodide (PI) is normally used as a second dye to distinguish between early and late apoptosis as well as necrosis (33). In addition, a nucleus-staining fluorescent dye, Hoechst 33342 (200 $\mu \mathrm{g} / \mathrm{ml}, 1: 40$; AppliChem GmbH, Darmstadt, Germany) 
Table I. Pelargonium species used in folk medicine.

Genus: Pelargonium

plant species

$P$. reniforme and

$P$. sidoides

P. graveolens

P. endlicherianum

P. radula

P. betulinum

P. cucullatum

P. glutinosum

P. citronellum
Traditional uses (ref)

Screened parts

Previously screened

activity (ref)

Roots

Antimycobacterial $(12,16)$

Coughs, diarrhoea, hepatic

disorders and tuberculosis $(14,15)$

(roots)

Antiasthmatic, antiallergic,

antidiarrhoeic, diuretic, tonic,

Aerial parts

Antioxidant (13) and anticancer $(13,18)$

hemostatic, anti-hepatotoxic,

stomachic and diabetic (17)

(leaves and flowers)

Anthelmintic (19)

(roots and flowers)

Mosquito repellent (22)

(leaves and flowers)

Coughs and other chest problems,

wound healing and gastrointestinal-

related problems (24) (leaves)

Colic, diarrhoea and wounds (24)

(leaves)

Astringent (25) (all parts)

Aerial parts

and roots

Antioxidant (20) and

Leaves

antimicrobial (21)

Antimicrobial (23)

Aerial parts

Antibacterial and

antioxidant (8)

Aerial parts

Stems and leaves

Antibacterial and antioxidant (8)

Antibacterial, antioxidant and cytotoxic (8)

Antibacterial and cytotoxic (8) was used in the present study to detect apoptosis on the basis of nuclear morphology. Hoechst 33342 dye stains all types of cells (alive and dead) (34). While early apoptotic cells are considered only Annexin-V-FITC-positive, late apoptotic cells (or secondary necrotic cells) are considered both Annexin-V-FITC- and PI-positive, with the presence of pyknotic nuclei and/or condensed chromatin $(33,34)$. Briefly, A549, PC3 and H1299 cells were seeded in a 96-well plate at a density of $1 \times 104$ cells/well, and treated for 12 and $24 \mathrm{~h}$ with PQE at a dose of $100 \mu \mathrm{g} / \mathrm{ml}$. Upon treatment, cells were stained with Annexin-V-FITC and PI using the Annexin-V-FLUOS Staining kit (Roche Diagnostics GmbH, Mannheim, Germany), according to the manufacturer's protocol. The cells were then visualized under a fluorescence microscope.

M30 and M65 assays. Intact cytokeratin 18 (CK18, also known as M65) and caspase-cleaved CK18 (also known as M30) were measured using M30-Apoptosense ${ }^{\circledR}$ and M65 EpiDeath ${ }^{\circledR}$ enzyme-linked immunosorbent assay (ELISA) kits (Vivalavida AB, Nacka, Sweden). The M30-Apoptosense ${ }^{\circledR}$ ELISA kit measures the levels of M30 produced during apoptosis, while the M65 EpiDeath ${ }^{\circledR}$ ELISA kit measures the levels of both caspase-cleaved and intact CK18, which is released from cells undergoing necrosis (35). A total of $1 \times 10^{4}$ A549, PC3 or H1299 cells were seeded per well in a 96-well plate in $200 \mu \mathrm{l}$ culture medium in triplicates. After $24 \mathrm{~h}$, cells were treated with PQE $(100 \mu \mathrm{g} / \mathrm{ml})$ for $48 \mathrm{~h}$. At the end of the treatment period, cells were lysed with $10 \%$ NP-40 (Sigma-Aldrich) for $10 \mathrm{~min}$ on a shaker to perform the M30 assay, while the supernatants were collected for the M65 assay, according to the manufacturer's protocol. The absorbance was determined with an ELISA reader at $450 \mathrm{~nm}$ (FLASH Scan S12 ${ }^{\circledR}$; Analytik Jena AG, Jena, Germany).

Western blot analysis for further dissection of the apoptosis mechanism. A549, PC3 and H1299 cells were seeded in $25-\mathrm{cm}^{2}$ flasks, and treated with PQE $(100 \mu \mathrm{g} / \mathrm{ml})$ for $24 \mathrm{~h}$ when the cells reached $70 \%$ confluency. Additionally, cisplatin $(20 \mu \mathrm{M})$ for A549 and PC3 cells, and etoposide $(5 \mu \mathrm{M})$ for H1299 cells, were used as positive controls for cleaved-poly (adenosine diphosphate-ribose) polymerase (PARP) (36-38). Cells were lysed in radioimmunoprecipitation assay lysis buffer (Santa Cruz Biotechnology, Inc., Dallas, TX, USA), containing protease inhibitors. Equal amounts of protein (20 $\mu \mathrm{g}$ protein/lane) were subjected to $12 \%$ sodium dodecyl sulfate-polyacrylamide gel electrophoresis (SDS-PAGE) and then transferred to a nitrocellulose membrane (Thermo Fisher Scientific, Inc.). Western blotting was performed using rabbit anti- $\beta$-actin and anti-PARP monoclonal antibodies at 1:1,000 dilution (catalog nos., 4970 and 9532, respectively; Cell Signaling Technology, Inc., Danvers, MA, USA) in 5\% (w/v) bovine serum albumin (Amresco, LLC, Solon, OH, USA). Horseradish peroxidase (HRP)-linked anti-rabbit immunoglobulin $\mathrm{G}$ antibody (1:2,000 dilution; catalog no., 7074; Cell Signaling Technology, Inc.) was used to detect anti- $\beta$-actin and anti-PARP antibodies. Secondary antibody detection was performed according to the instructions of Phototope ${ }^{\circledR}$-HRP Western Blot Detection System (Cell Signaling Technology, Inc.). Stripping was performed 
Table II. Chemical composition of Pelargonium quercetorum extract.

\begin{tabular}{lccc}
\hline Compound $^{\mathrm{a}}$ & ${ }^{1} \mathrm{tR}^{\mathrm{b}}$ & ${ }^{2} \mathrm{tR}^{\mathrm{b}}$ & Area $^{\mathrm{c}}$ \\
\hline Acetic acid & 430 & 1.30 & 0.65 \\
2,5-Dimethyl pyrazine & 510 & 2.05 & 0.61 \\
--Butyrolactone & 545 & 2.68 & 0.47 \\
Benzeneacetaldehyde & 740 & 2.35 & 0.11 \\
4-Hydroxy-2,5-dimethyl-3(2H)-furanone & 760 & 2.27 & 0.15 \\
2-Pyrrolidinone & 805 & 3.17 & 2.70 \\
5-Hydroxymethyldihydrofuran-2(3H)-one & 1025 & 3.19 & 0.36 \\
Hexahydrofarnesyl acetone & 1980 & 1.54 & 0.73 \\
Allyl octadecyl oxalate & 2000 & 0.57 \\
n-Tridecan-1-ol & 2045 & 1.37 & 0.94 \\
Ylangene & 2075 & 1.57 & 1.36 \\
Iso-palmitic methyl ester & 2090 & 1.70 & 0.14 \\
Nerolidol & 2490 & 1.52 & 0.11 \\
Farnesane & 2810 & 1.96 & 0.68 \\
Eicosane & 2900 & 1.37 & 5.15 \\
1-Tetracosanol & 2920 & 1.42 & 2.61 \\
3,7-Dimethylnonane & 2965 & 1.56 & 0.70 \\
1-Hexadecanol & 2990 & 1.48 & 1.06 \\
1-Octadecanol acetate & 3005 & 1.45 & 2.63 \\
Heneicosane & 3075 & 1.53 & 16.23 \\
2-Methyleicosane & 3150 & 1.56 & 12.37 \\
Tetracosane & 3235 & 1.45 & 40.92 \\
Oleic acid & 3315 & 1.59 & 0.85 \\
Unknown & $=$ & 3.81 & 7.86 \\
\hline
\end{tabular}

${ }^{a}$ As identified by LECO GCxGC-TOF/MS ChromaTOF ${ }^{\circledR}$ version 2.3 software (LECO Corporation, Saint Joseph, MI, USA). The compounds were named according to the 2005 Automated Mass Spectral Deconvolution and Identification System (National Institute of Standards and Technology, US Department of Commerce) (39). ${ }^{\mathrm{b}} \mathrm{tR}$ and ${ }^{\mathrm{t}} \mathrm{tR}$, retention times in the first and second dimension, respectively. ${ }^{\mathrm{c} T h e}$ percentage of each component was calculated as the peak area of the analyte divided by the peak area of the total ion chromatogram and multiplied by 100 .

according to the manufacturer's reprobing protocol (Cell Signaling Technology, Inc.). Bound antibodies were visualized on a FUSION-FX7 imaging device (Vilber Lourmat, Marne-la-Vallée, France).

Statistical analysis. All statistical analysis were performed using SPSS 20.0 statistical software (IBM SPSS, Armonk, NY, USA). The significance was calculated using one-way analysis of variance. Significant differences in the M30 and M65 assays were determined using the Student's $t$ test. $\mathrm{P}<0.05$ was considered to indicate a statistically significant difference. The results were expressed as the mean \pm standard deviation.

\section{Results}

ChemicalcompositionofP.quercetorum.The volatilecompounds of $P$. quercetorum were analyzed by GCxGC-TOF/MS (39), and the qualitative and quantitative compositions were presented in Table II. A total of 23 compounds were identified in P. quercetorum, and the major components were tetracosane (40.92\%), heneicosane (16.23\%), 2-methyleicosane (12.37\%), eicosane (5.15\%), 2-pyrrolidinone (2.70\%), octadecanol acetate (2.63\%), 1-tetracosanol (2.61\%), ylangene (1.36\%) and 1-hexadecanol
$(1.06 \%)$. The rate of unknown compounds was $7.86 \%$. All other components were present in $<1 \%$.

Anti-growth/cytotoxic effect of PQE by ATP assay. The cytotoxic effect of PQE on non-small cell lung cancer cell lines (A549, PC3 and H1299) were screened by ATP viability assay. Cells were treated with increasing doses of PQE $(3.13-100 \mu \mathrm{g} / \mathrm{ml})$ for $48 \mathrm{~h}$. As shown in Fig. 1A, PQE significantly reduced the cell viability levels in a dose-dependent manner $(\mathrm{P}<0.05)$. $\mathrm{PQE}$ exhibited stronger anti-growth effect on PC3 cells at relatively lower doses, compared with A549 and H1299 cells. The cell death was clearly evident in all cell lines by phase-contrast microscopy (Fig. 1B). The inhibitory concentration (IC) $)_{50}$ and $\mathrm{IC}_{90}$ values were calculated on the basis of the results of the ATP assay (Table III).

Fluorescence staining for confirmation of cell death mode. Annexin-V-FITC staining was performed in order to determine the presence of apoptosis and to distinguish early-from late-stage apoptosis. Hoechst dye 33342 was additionally used. Cells were treated with PQE $(100 \mu \mathrm{g} / \mathrm{ml})$ for 12 and $24 \mathrm{~h}$. The images of 24-h treatment are shown in Figs. 2-4. The early apoptotic cells were positively stained for only Annexin-V-FITC (green), while 
A

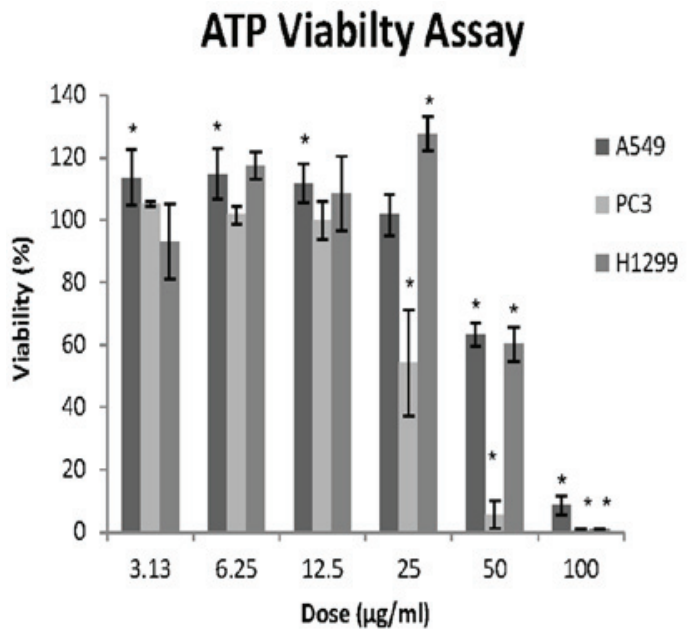

B

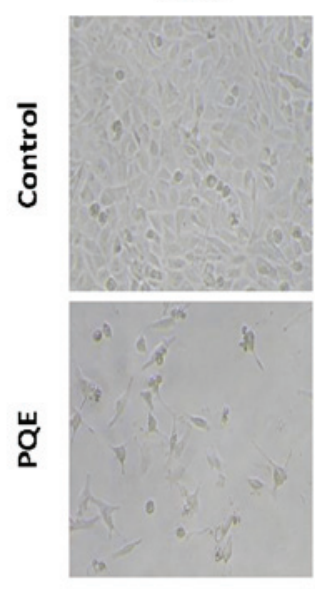

PC3

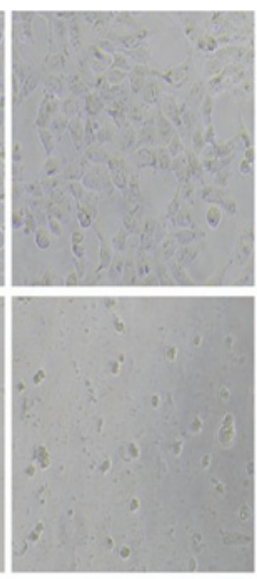

H1299

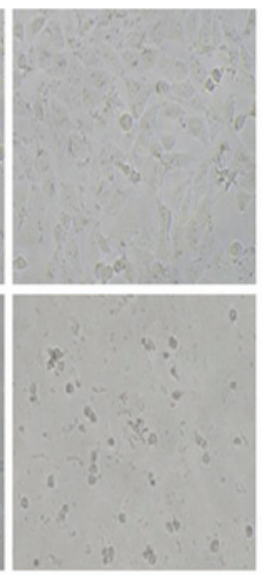

Figure 1. (A) The anti-growth effect of PQE after 48-h treatment in non-small cell lung cancer cell lines was determined by adenosine triphosphate assay. (B) Representative images of cells were captured under a phase-contrast microscope using $10 \mathrm{x}$ magnification after exposure to $100 \mu \mathrm{g} / \mathrm{ml} \mathrm{PQE}$ for $48 \mathrm{~h}$. ${ }^{*} \mathrm{P}<0.05$ vs. control group receiving vehicle only ( $0.1 \%$ dimethyl sulfoxide). ATP, adenosine triphosphate; $\mathrm{PQE}$, Pelargonium quercetorum extract.

the late apoptotic cells (also called secondary necrotic cells) were positively stained for PI (red). The presence of pyknotic nuclei (thin white arrows) on either early (yellow short arrows) or late (white short arrows) apoptotic cells was a well-known proof of apoptotic cell death (Figs. 2-4).

Levels of total/intact and caspase-cleaved CK18 for cell death modes. Two different ELISAs were used, one for the estimation of total CK18 (M65, for primary or secondary necrosis) and the other one for the estimation of caspase-cleaved CK18 (M30, for apoptosis). Fig. 5A indicates that the levels of M30 did not change in A549, PC3 or H1299 cells after 48-h PQE treatment, implying that the apoptosis resulted from PQE may not reach the fragmentation of the cytoskeleton. However, it is notable that M30 was substantially increased in A549 cells after treatment with paclitaxel, which is a positive control for caspase-cleaved CK18 ( $\mathrm{P}=0.053$ ) (data not shown).

With regard to M65 levels, they were observed to increase 6-fold in PC3 and H1299 cells, and 4-fold in A549 cells, after treatment with PQE $(100 \mu \mathrm{g} / \mathrm{ml})$ for $48 \mathrm{~h}$, compared with untreated control cells (Fig. 5B). These increments may have resulted from secondary necrosis that normally occurs following apoptosis.

Detection of PARP cleavage by western blotting. The cleavage of PARP was assayed by western blotting to further dissect the mechanism of apoptosis. Cisplatin and etoposide were used as positive controls for PARP-cleavage. It was observed that PARP was not cleaved in A549, PC3 or H1299 cell lines following the treatment with PQE $(100 \mu \mathrm{g} / \mathrm{ml})$ for $24 \mathrm{~h}$ (Fig. 6). The lack of cleavage of PARP was considered as incomplete apoptosis, rather than typical apoptosis.

\section{Discussion}

Lung cancer is the leading cause of cancer-associated mortalities worldwide due to its high incidence and mortality (40). Despite novel chemotherapy regimens, there is not sufficient success in its treatment. Therefore, new therapeutic approaches
Table III. $\mathrm{IC}_{50}$ and $\mathrm{IC}_{90}$ values of Pelargonium quercetorum extract in non-small cell lung cancer cells lines.

\begin{tabular}{lccc}
\hline Dose $(\mu \mathrm{g} / \mathrm{ml})$ & A549 & PC3 & H1299 \\
\hline $\mathrm{IC}_{50}$ & $62.13 \pm 1.90$ & $27.18 \pm 3.21$ & $58.53 \pm 2.96$ \\
$\mathrm{IC}_{90}$ & $98.70 \pm 1.64$ & $47.73 \pm 1.36$ & $92.43 \pm 0.60$
\end{tabular}

$\mathrm{IC}_{50}$, concentration inhibiting $50 \%$ of cell growth (viability). $\mathrm{IC}_{90}$, concentration inhibiting $90 \%$ of cell growth (viability). Values are shown as the mean \pm standard deviation.

would be instrumental for better management of lung cancer patients. Since natural products are important in cancer therapy, the present study was conducted to evaluate the possible anti-growth/cytotoxic activity of PQE on lung cancer cell lines. Despite the fact that there are several studies on the anticancer activity of the Pelargonium genus $(13,41)$, the present study is the first one in the literature to demonstrate the cytotoxic activity of $P$. quercetorum on non-small cell lung cancer cell lines (A549, PC3 and H1299).

In the present study, $P$. quercetorum was observed to exert a significant anti-growth effect against A549, PC3 and H1299 lung cancer cell lines in a dose-dependent manner. According to the ATP assay results, the $\mathrm{IC}_{50}$ values were 62.1, 27.2 and $58.5 \mu \mathrm{g} / \mathrm{ml}$ for A549, PC3 and $\mathrm{H} 1299$ cell lines, respectively. In a previous study in which the crude acetone extracts of different Pelargonium species were used against transformed human kidney epithelium (Graham) cells, it was reported that the $\mathrm{IC}_{50}$ values of $P$. sublignosum, $P$. citronellum, $P$. graveolens, $P$. betulinum, $P$. capitatum and $P$. tomentosum were 11.9, 59.9, 83.3, $88.5,101.5$ and $195.1 \mu \mathrm{g} / \mathrm{ml}$, respectively (8). This variability of $\mathrm{IC}_{50}$ values may be due to the use of different solvents for the extraction process or the different composition of the plant itself. In fact, biological activities of different species may vary by essential oil components.

A large number of Pelargonium species are aromatic and comprise geranium essential oil, which is one of the 


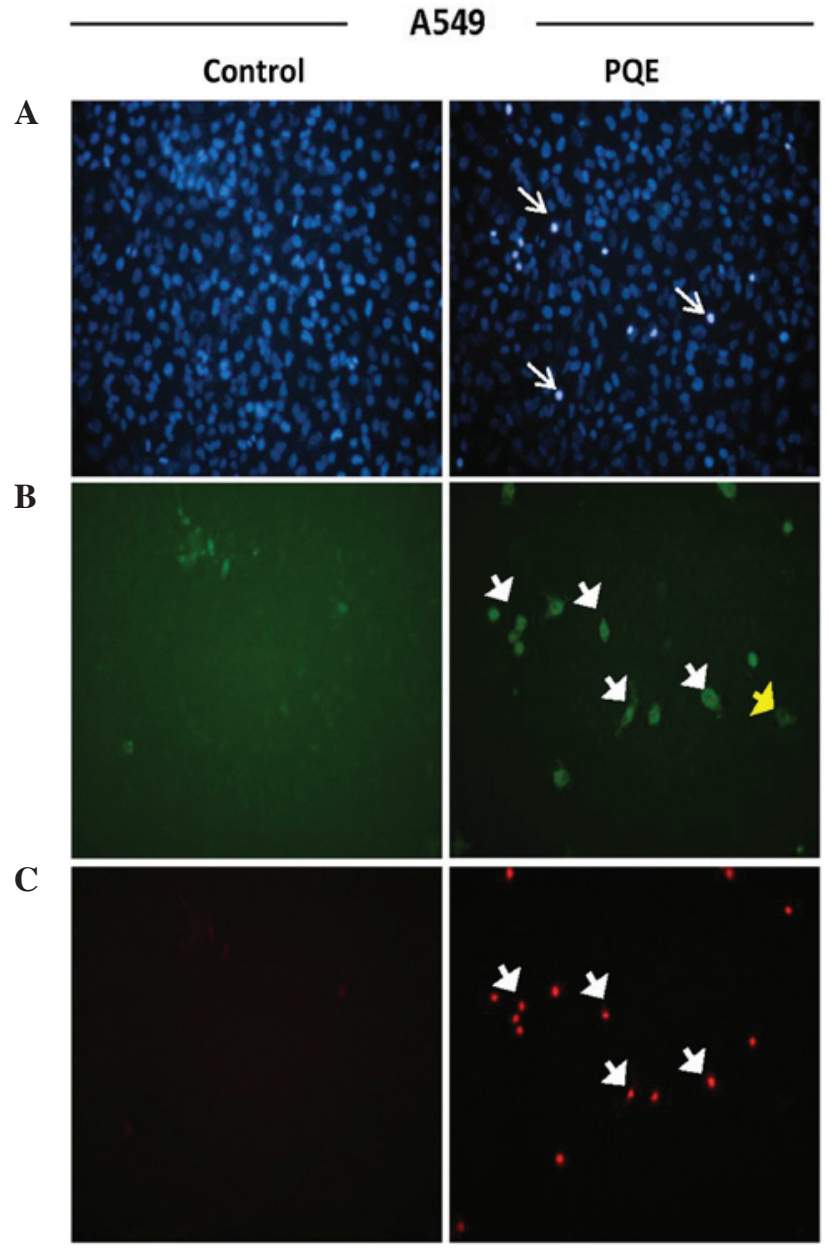

Figure 2. Fluorescence imaging for determination of cell death mode of A549 cells. Cells were treated with PQE $(100 \mu \mathrm{g} / \mathrm{ml})$ for $24 \mathrm{~h}$ and subsequently stained with (A) Hoechst 33342, (B) Annexin-V-FITC and (C) PI. Thin white arrows indicate the pyknotic nuclei of apoptotic cells, while yellow short arrows indicate the presence of Annexin-V-FITC staining for early-stage apoptosis, and white short arrows indicate the presence of both Annexin-V-FITC and PI staining for late-stage apoptosis (secondary necrosis). PQE, Pelargonium quercetorum extract; FITC, fluorescein isothiocyanate; PI, propidium iodide.

top 20 essential oils in the world $(9,42)$. It is known that geranium essential oils exhibit anticancer activity $(43,44)$. Therefore, in addition to certain unknown compounds, $P$. quercetorum-derived essential oils may be responsible for this cytotoxic effect. Despite the fact that these oils could not be analyzed in the present study, an extensive analysis of the chemical composition identified by GCxGC-TOF/MS was conducted (Table II). On the basis of this analysis, it was noticed that tetracosane, heneicosane and 2-methyleicosane were the most abundant components in P. quercetorum.

Furthermore, the present study investigated the mode of cell death resulted from PQE. Firstly, the morphology of the cells nuclei was evaluated for the presence of any apoptosis. The nuclei were observed to be pyknotic, implying that the mode of cell death was apoptosis, which was confirmed by Annexin-V positivity. To dissect further the mechanism of cell death/apoptosis, both the caspase-cleaved CK18 (M30) and intact CK18 (M65) levels were also measured. These assays perfectly discriminate two main cell death modes, apoptosis or necrosis (35). No increase in M30 levels was observed in these cell lines after

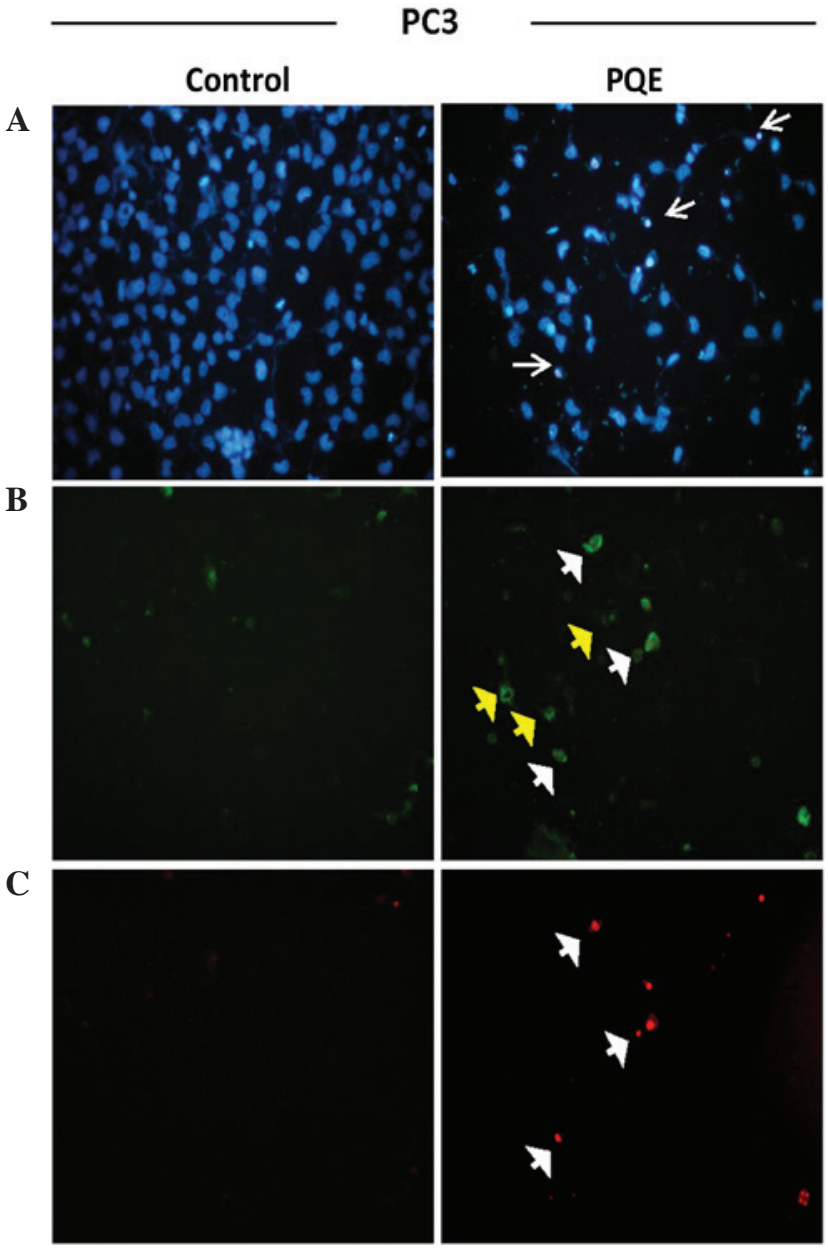

Figure 3. Fluorescence imaging for determination of cell death mode of PC 3 cells. Cells were treated with PQE $(100 \mu \mathrm{g} / \mathrm{ml})$ for $24 \mathrm{~h}$ and subsequently stained with (A) Hoechst 33342, (B) Annexin-V-FITC and (C) PI. Thin white arrows indicate the pyknotic nuclei of apoptotic cells, while yellow short arrows indicate the presence of Annexin-V-FITC staining for early-stage apoptosis, and white short arrows indicate the presence of both Annexin-V-FITC and PI staining for late-stage apoptosis (secondary necrosis). PQE, Pelargonium quercetorum extract; FITC, fluorescein isothiocyanate; PI, propidium iodide.

treatment with PQE, despite the fact that the Annexin-V-FITC staining of the cell membrane and the morphological evaluation of the cell nuclei clearly implied an apoptotic cell death. For the lack of M30 increase, there could be two reasons, one being the lack of CK18 in the cells, and the other one being no fragmentation of CK18 actually occurring. The present authors recently reported that all the cell lines evaluated in the present study expressed CK18, being A549 cells the ones that exhibited the highest levels (45). This result implies that the apoptotic process may not include the fragmentation of CK18. That is why the type of cell death observed in the present study was described as incomplete apoptosis. Regarding the M65 levels, the explanation of increases in M65 levels is that the cells should be undergoing secondary necrosis following apoptosis (46).

In order to additionally investigate the mechanism of apoptosis, the levels of PARP, which are normally cleaved by active caspase-3 during apoptosis, were evaluated by the present study $(47,48)$. No significant alterations in the cleaved PARP levels were observed compared with untreated control cells by western blot analysis. Therefore, the present authors would like 


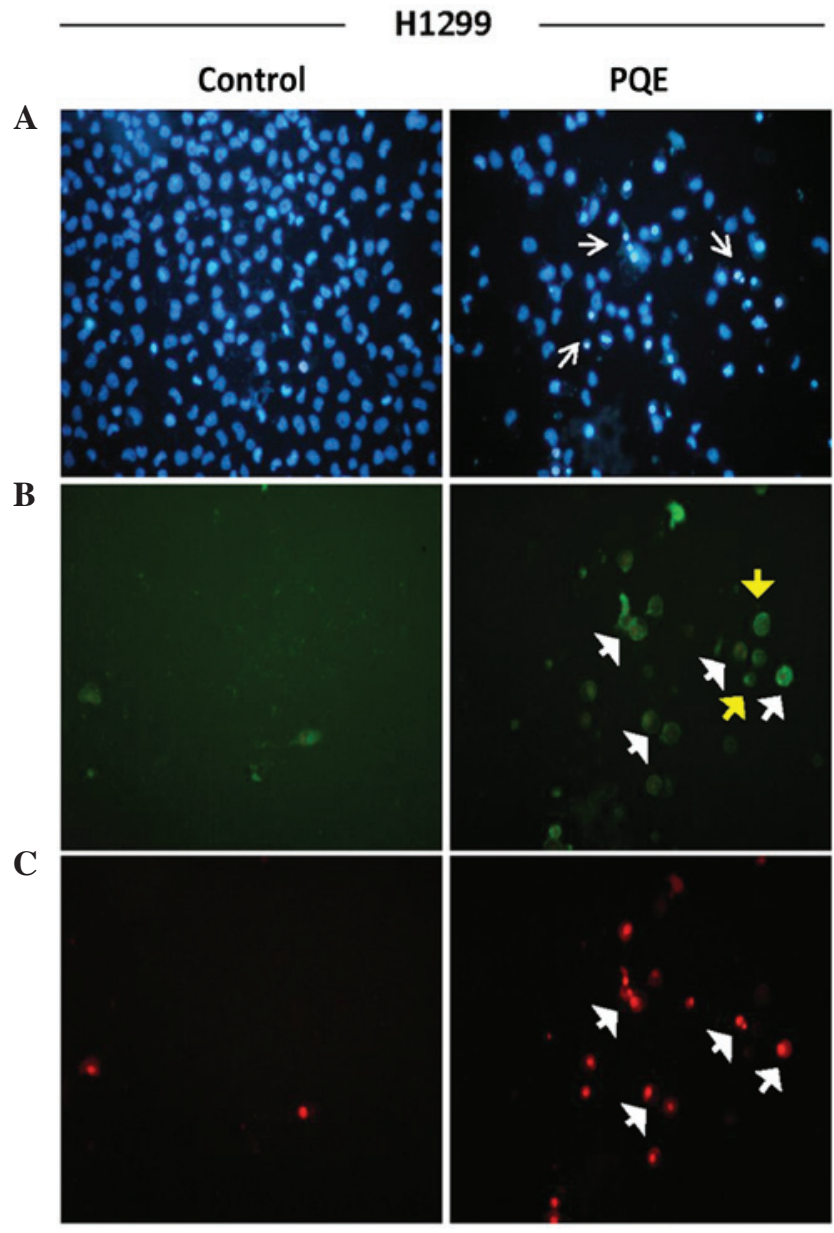

Figure 4. Fluorescence imaging for determination of cell death mode of H1299 cells. Cells were treated with PQE $(100 \mu \mathrm{g} / \mathrm{ml})$ for $24 \mathrm{~h}$ and subsequently stained with (A) Hoechst 33342, (B) Annexin-V-FITC and (C) PI. Thin white arrows indicate the pyknotic nuclei of apoptotic cells, while yellow short arrows indicate the presence of Annexin-V-FITC staining for early-stage apoptosis, and white short arrows indicate the presence of both Annexin-V-FITC and PI staining for late-stage apoptosis (secondary necrosis). PQE, Pelargonium quercetorum extract; FITC, fluorescein isothiocyanate; PI, propidium iodide.

to refer to the resultant cell death in the present study as either incomplete apoptosis or apoptosis-like cell death. The latter is highly possible, since numerous different types of cell death have recently emerged (49). However, there are no data in the literature that could be used for comparison with results of the present study. Since both M30 production and PARP cleavage have been demonstrated to result from caspase-activation (50), it is reasonable to conclude that in the present study the cell death resulted from PQE may be caspase-independent. However, this should be the topic of future studies, as additional extensive experiments are required to elucidate this point.

To the best of our knowledge, the present is the first study to demonstrate the anti-growth/cytotoxic activity of $P$. quercetorum in non-small cell lung cancer cells, warranting further evaluation in vivo for proof of concept.

\section{Acknowledgements}

The authors would like to thank the Research Fund of Uludag University (Bursa, Turkey) for funding the present
A

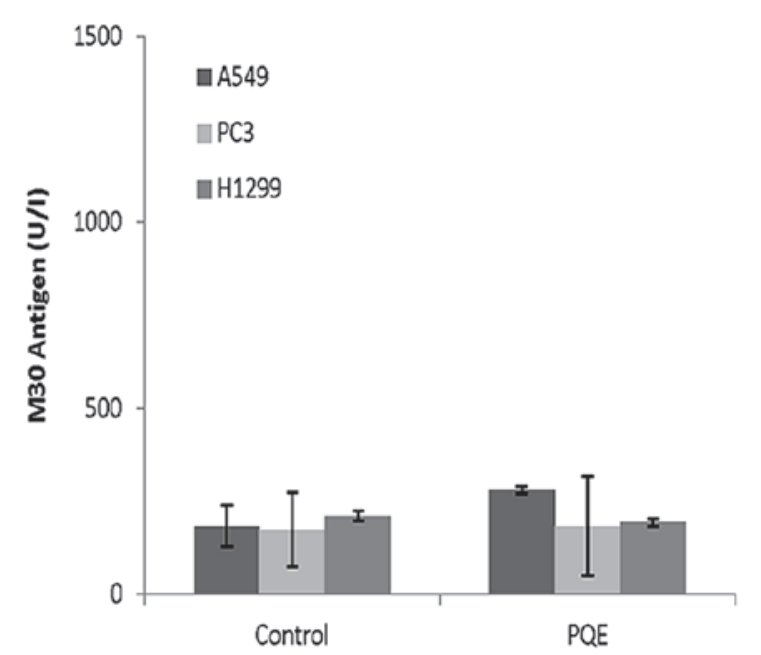

B

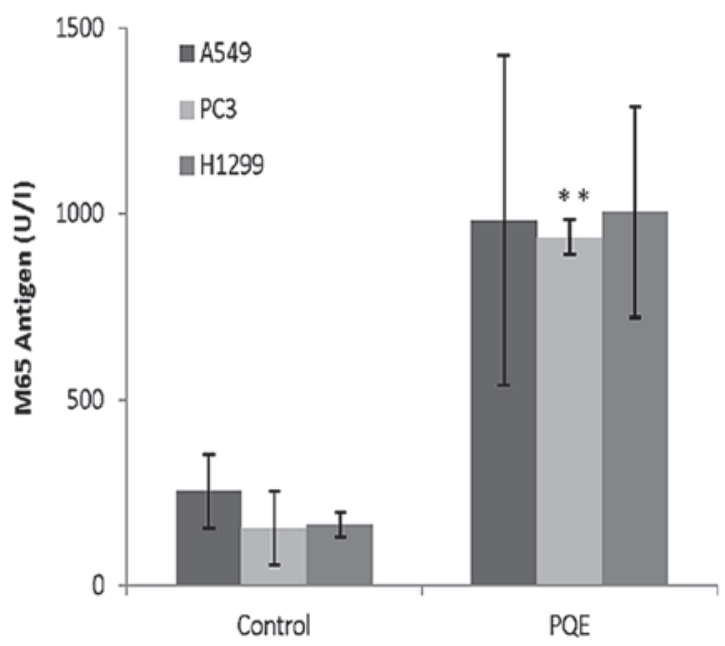

Figure 5. Levels of M30 and M65 after treatment with Pelargonium quercetorum extract (100 $\mu \mathrm{g} / \mathrm{ml})$ for $48 \mathrm{~h}$. (A) M30 and (B) M65 were measured by enzyme-linked immunosorbent assay. ${ }^{* *} \mathrm{P}<0.01$ vs. control group receiving vehicle only ( $0.1 \%$ dimethyl sulfoxide). PQE, Pelargonium quercetorum extract.

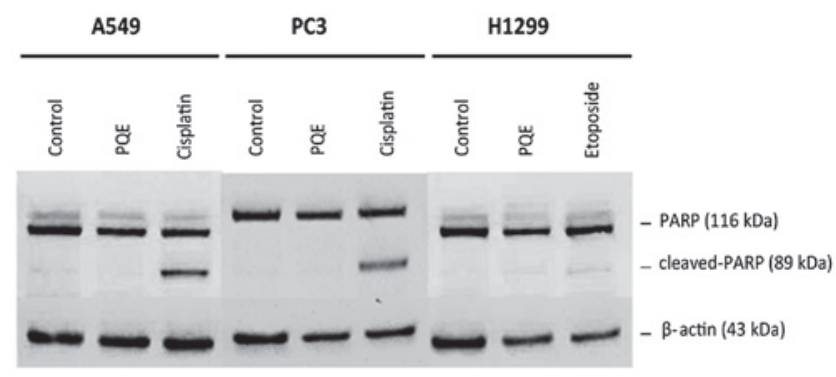

Figure 6. Western blot analysis of poly (adenosine diphosphate-ribose) polymerase in A549, PC3 and H1299 cell lines. $\beta$-actin was used as loading control. The treatment was conducted for $24 \mathrm{~h}$. Vertical and horizontal lanes indicate separate blots. PQE, Pelargonium quercetorum extract; PARP, poly (adenosine diphosphate-ribose) polymerase.

study [project number UAP (F)-2012/17] and for providing the kits/chemicals required. The authors would also like to thank Dr Aysegul Cebi (Giresun University, Giresun, Turkey) for providing the plant; Dr Serap Celikler (Uludag University, Bursa, Turkey) for contributing to the extraction and lyophilization of the plant; and Dr Hakan Akca (Pamukkale 
University, Denizli, Turkey) for providing the cell lines used in the present study.

\section{References}

1. Sanders HR and Albitar M: Somatic mutations of signaling genes in non-small cell lung cancer. Cancer Genet Cytogenet 203: 7-15, 2010.

2. Jemal A, Siegel R, Xu J and Ward E: Cancer statistics, 2010. CA Cancer J Clin 60: 277-300, 2010.

3. Halberstein RA: Medicinal plants: Historical and cross-cultural usage patterns. Ann Epidemiol 15: 686-699, 2005.

4. Ayo RG: Phytochemical constituents and bioactivities of the extracts of Cassia nigricans Vahl. J Med Plant Res 14: 1339-1348, 2010.

5. Cragg GM and Newman DJ: Plants as a source of anti-cancer agents. J Ethnopharmacol 100: 72-79, 2005.

6. Latté KP and Kolodziej H: Antioxidant properties of phenolic compounds from Pelargonium reniforme. J Agric Food Chem 52: 4899-4902, 2004

7. Kolodziej H: Pelargonium reniforme and Pelargonium sidoides: Their botany, chemistry and medicinal use. In: Geranium and Pelargonium, Series: Medicinal and Aromatic Plants - Industrial Profiles. Lis-Balchin M (ed). Vol 27, Taylor and Francis, London, pp262-290, 2002.

8. Lalli JYY, Van Zyl RL, Van Vuuren SF and Viljoen AM: In vitro biological activities of South African Pelargonium (Geraniaceae) species. South African Journal of Botany 74: 153-157, 2008.

9. Saraswathi J, Venkatesh K, Baburao N, Hilal MH and Rani AR: Phytopharmacological importance of Pelargonium species. J Med Plant Res 5: 2587-2598, 2011.

10. Yanishlieva NV, Marinova E, Gordon MH and Raneva VG: Antioxidant activity and mechanism of action of thymol and carvacrol in two lipid systems. Food Chem 64: 59-66, 1999.

11. Kris-Etherton PM, Hecker VK, Bonanome A, Coval SM, Binkoski AE, Hilpert KF, Griel AE and Etherton TD: Bioactive compounds in foods: Their role in the prevention of cardiovascular disease and cancer. Am J Med 113 (Suppl 9B): 71S-88S, 2002.

12. Seidel V and Taylor PW: In vitro activity of extracts and constituents of Pelargonium against rapidly growing mycobacteria. Int J Antimicrob Agents 23: 613-619, 2004.

13. Fayed S: Antioxidant and anticancer activities of Citrus reticulate (Petitgrain mandarin) and Pelargonium graveolens (Geranium) essential oils. Research Journal of Agriculture and Biological Sciences 5: 740-747, 2009.

14. Kolodziej H: Fascinating metabolic pools of Pelargonium sidoides and Pelargonium reniforme, traditional and phytomedicinal sources of the herbal medicine Umckaloabo. Phytomedicine 14 (Suppl 6): 9-17, 2007.

15. Moyo M and Van Staden J: Medicinal properties and conservation of Pelargonium sidoides DC. J Ethnopharmacol 152 243-255, 2014.

16. Mativandlela SPN, Lall N and Meyer JJM: Antibacterial, antifungal and antitubercular activity of (the roots of) Pelargonium reniforme (CURT) and Pelargonium sidoides (DC) (Geraniaceae) root extracts. South African Journal of Botany 72: 232-237, 2006

17. Boukhris M, Bouaziz M, Feki I, Jemai H, El Feki A and Sayadi S: Hypoglycemic and antioxidant effects of leaf essential oil of Pelargonium graveolens L'Hér. in alloxan induced diabetic rats. Lipids in health and disease 11: 81, 2012.

18. Fang HJ, Su XL, Liu HY, Chen YH and Ni JH: Studies on the chemical components and anti-tumour action of the volatile oils from Pelargonium graveoleus. Yao Xue Xue Bao 24: 366-371, 1989 (In Chinese).

19. Bozan B, Ozek T, Kurkcuoglu M, Kirimer N and Can Baser KH: The analysis of essential oil and head space volatiles of the flowers of Pelargonium endlicherianum used as an anthelmintic in folk medicine. Planta Medica 65: 781-782, 1999.

20. Tepe B, Sokmen M, Akpulat HA, Yumrutas O and Sokmen A: Screening of antioxidative properties of the methanolic extracts of Pelargonium endlicherianum Fenzl., Verbascum wiedemannianum Fisch. and Mey., Sideritis libanotica Labill. subsp. lineraris (Bentham) Borm., Centaurea mucronifera DC. and Hieracium cappadocicum Freyn from Turkish flora. Food Chemistry 98: 9-13, 2006.
21. Ozbilge H, Kaya EG, Taskin OM and Kosar M: Antimicrobial activity of Pelargonium endlicherianum Fenzl. (Geraniaceae) roots against some microorganisms. J Med Plant Res 4: 2647-2650, 2010

22. Asnawi S, Mohd ZZ, Abdul Aziz A, Khamis AK and Abdul Aziz B: Evaluation of the potential of Pelargonium Radula extract in repelling Aedes Aegypti. Journal of Chemical \& Natural Resources Engineering 2: 11-19, 2008.

23. Lis-Balchin M, Buchbauer G, Ribisch K and Wenger MT: Comparative antibacterial effects of novel Pelargonium essential oils and solvent extracts. Lett Appl Microbiol 27: 135-141, 1998.

24. Scott G, Springfield EP and Coldrey N: A pharmacognostical study of 26 South African plant species used as traditional medicines. Pharmaceutical Biology 42: 186-213, 2004

25. Grieve M: Tansy. In: A Modern Herbal: The Medicinal, Culinary, Cosmetic and Economic Properties, Cultivation and Folklore of Herbs, Grasses, Fungi, Shrubs and Trees with All Their Modern Scientific Uses. Leyel CF (ed). Penguin, Middleburg, pp789-790, 1984.

26. Bown D (ed): The Herb Society of America New Encyclopedia of Herbs and Their Uses. Dorling Kindersley Publishing Inc., New York, NY, 1995.

27. Kaval I, Behçet L and Cakilcioglu U: Ethnobotanical study on medicinal plants in Geçitli and its surrounding (Hakkari-Turkey). J Ethnopharmacol 155: 171-184, 2014.

28. Davis PH ed): Flora of Turkey and the East Aegean Islands. Vol. 1. Edinburgh University Press, Edinburgh, pp1, 1965.

29. Davis PH, Mill RR and Tan K (eds): Flora of Turkey and the east Aegean Islands. Vol. 10 (Suppl 1). Edinburgh Universitys Press, Edinburgh, pp106, 1988.

30. Andreotti PE, Cree IA, Kurbacher CM, Hartmann DM, Linder D, Harel G, Gleiberman I, Caruso PA, Ricks SH, Untch M, et al: Chemosensitivity testing of human tumors using a microplate adenosine triphosphate luminescence assay: Clinical correlation for cisplatin resistance of ovarian carcinoma. Cancer Res 55: 5276-5282, 1995

31. Ari F, Aztopal N, Icsel C, Yilmaz VT, Guney E, Buyukgungor O and Ulukaya E: Synthesis, structural characterization and cell death-inducing effect of novel palladium(II) and platinum(II) saccharinate complexes with 2-(hydroxymethyl) pyridine and 2-(2-hydroxyethyl) pyridine on cancer cells in vitro. Bioorg Med Chem 21: 6427-6434, 2013.

32. Ulukaya E, Acilan C, Ari F, Ikitimur E and Yilmaz Y: A glance at the methods for detection of apoptosis qualitatively and quantitatively. Turkish Journal of Biochemistry 36: 261-269, 2011.

33. Hammill AK, Uhr JW and Scheuermann RH: Annexin V staining due to loss of membrane asymmetry can be reversible and precede commitment to apoptotic death. Exp Cell Res 251: 16-21, 1999.

34. Zhang G, Gurtu V, Kain SR and Yan G: Early detection of apoptosis using a fluorescent conjugate of annexin V. Biotechniques 23: 525-531, 1997.

35. Linder S, Olofsson MH, Herrmann R and Ulukaya E: Utilization of cytokeratin-based biomarkers for pharmacodynamic studies. Expert Rev Mol Diagn 10: 353-359, 2010.

36. Chiu CC, Lin CH and Fang K: Etoposide (VP-16) sensitizes p53-deficient human non-small cell lung cancer cells to caspase-7-mediated apoptosis. Apoptosis 10: 643-650, 2005.

37. Dasgupta P, Kinkade R, Joshi B, DeCook C, Haura E and Chellappan S: Nicotine inhibits apoptosis induced by chemotherapeutic drugs by up-regulating XIAP and survivin. Proc Natl Acad Sci USA 103: 6332-6337, 2006.

38. Zhang X, Ling MT, Wong YC and Wang X: Evidence of a novel antiapoptotic factor: Role of inhibitor of differentiation or DNA binding (Id-1) in anticancer drug-induced apoptosis. Cancer Sci 98: 308-314, 2007.

39. NIST: Automated Mass Spectral Deconvolution and Identification System 2005 version. National Institute of Standards and Technology, US Department of Commerce, USA, 2005.

40. Jemal A, Bray F, Center MM, Ferlay J, Ward E and Forman D: Global Cancer Statistics. CA Cancer J Clin 61: 69-90, 2011.

41. de Moura MD, Silva JDS, de Oliveira RAG, Diniz MDFFM and Barbosa-Filho JM: Natural products reported as potential inhibitors of uterine cervical neoplasia. Acta Farmacéutica Bonaerense 21: 67-74, 2002.

42. Lis-Balchin M: Geranium oil. International Journal of Aromatherapy 7: 18-20, 1996.

43. Haag JD, Lindstrom MJ and Gould MN: Limonene-induced regression of mammary carcinomas. Cancer Res 52: 4021-4026, 1992. 
44. Zhuang SR, Chen SL, Tsai JH, Huang CC, Wu TC, Liu WS, Tseng HC, Lee HS, Huang MC, Shane GT, et al: Effect of citronellol and the Chinese medical herb complex on cellular immunity of cancer patients receiving chemotherapy/radiotherapy. Phytother Res 23: 785-790, 2009.

45. Cevatemre B, Ulukaya E, Sarimahmut M, Oral AY and Frame FM The M30 assay does not detect apoptosis in epithelial-derived cancer cells expressing low levels of cytokeratin 18. Tumor Biol 36 : 6857-6865, 2015.

46. Ulukaya E, Acilan C and Yilmaz Y: Apoptosis: Why and how does it occur in biology? Cell Biochem Funct 29: 468-480, 2011.

47. Nicholson DW, Ali A, Thornberry NA, Vaillancourt JP, Ding CK, Gallant M, Gareau Y, Griffin PR, Labelle M, Lazebnik Y, et al: Identification and inhibition of the ICE/CED-3 protease necessary for mammalian apoptosis. Nature 376: 37-43, 1995.
48. Alnemri ES: Mammalian cell death proteases: A family of highly conserved aspartate specific cysteine proteases. J Cell Biochem 64: 33-42, 1997.

49. Galluzzi L, Vitale I, Abrams JM, Alnemri ES, Baehrecke EH, Blagosklonny MV, Dawson TM, Dawson VL, El-Deiry WS, Fulda S, et al: Molecular definitions of cell death subroutines: Recommendations of the Nomenclature Committee on Cell Death 2012. Cell Death Differ 19: 107-120, 2012.

50. Gown AM and Willingham MC: Improved detection of apoptotic cells in archival paraffin sections: Immunohistochemistry using antibodies to cleaved caspase 3. J Histochem Cytochem 50: 449-454, 2002. 